\title{
Kampus Merdeka Dalam Perspektif Pemikiran Ki Hajar Dewantara Dan Paulo Freire Serta Perdebatan Pemikiran Aliran Filsafat Pendidikan John Dewey Vs Robert M. Hutchins
}

\author{
${ }^{1}$ Agil Nanggala, ${ }^{2}$ Karim Suryadi \\ Pendidikan Kewarganegaraan, Universitas Pendidikan Indonesia \\ Email Korespondensi: agilnanggala@upi.edu
}

\begin{abstract}
Abstrak. Pemikiran pendidikan Ki Hajar Dewantara dan Paulo Freire mengenai kemerdekaan pada pendidikan, tentu menjadi telaah kritis bagi dunia akademik serta bahan pertimbangan pemerintah dalam memberlakukan kebijakan pendidikan. Termasuk pada penerapan kebijakan kampus merdeka yang begitu merepresentasikan perspektif pemikiran Ki Hajar Dewantara dan Paulo Freire, karena menghendaki untuk terjadinya kemerdekaan dan kebebasan dalam konsep dan praksis pendidikan, tentu substansi mengenai kebebasan dan modernisasi pendidikan, pada dasarnya diawali oleh gerakan pembaharuan pendidikan di Amerika dan Eropa Barat, sehingga perlu menganalisis perdebatan pemikiran progresivisme dan tradisional atau konservatif, melalui pemikiran John Dewey vs Robert M. Hutchins, sebagai tokoh penggagas aliran filsafat pendidikan tersebut, agar civitas akademika mengetahui posisinya pada perdebatan tersebut. Tentu penelitian ini dilakukan melalui pendekatan kualitatif dengan metode studi literatur, proses analisis data pada penelitian ini berfokus pada: reduksi data, display data, verifikasi serta penarikan kesimpulan. Hasil penelitiannya, sebagai berikut: 1) Kampus merdeka begitu merepresentasikan pemikiran pendidikan Ki Hajar Dewantara dan Paulo Freire, karena turut menghendaki terjadinya kemerdekaan serta kebebasan pada konsep serta praksis pendidikan, juga mengakomodir sistem among (membimbing serta melayani) bahkan pembelajaran kritis dan kreatif (hadap masalah), 2) Perdebatan pemikiran progresivisme John Dewey serta perenialisme Robert M. Hutchins, berfokus terhadap konsep, orientasi serta praksis pembelajaran, antara progres atau regres.
\end{abstract}

Kata kunci: Kampus Merdeka, Perdebatan Pemikian, Pendidikan

Abstract. The educational thoughts of Ki Hajar Dewantara and Paulo Freire regarding independence in education, of course, become a critical study for the academic world as well as material for the government's consideration in implementing educational policies. Including the implementation of the independent campus policy which so represents the perspective of the thoughts of Ki Hajar Dewantara and Paulo Freire, because they want independence and freedom in the concept and praxis of education, of course the substance of education freedom and modernization is basically initiated by the renewal movement of education in America and Europe. The West, so it is necessary to analyze progressivism and traditional or conservative thought debates, through the thoughts of John Dewey vs Robert M. Hutchins, as the initiator of the educational philosophy school, so that the academic community knows their position on the debate. Of course this research was carried out through a qualitative approach with the literature study method, the data analysis process in this study focused on: data reduction, data display, verification and drawing conclusions. The results of his research are as follows: 1) The independent campus represents the educational thinking of Ki Hajar Dewantara and Paulo Freire, because it also wants independence and freedom in the concept and praxis of education, also accommodates the among system (guiding and serving) even critical and creative learning (facing problems), 2) The debate on progressivism thinking of John Dewey and the perennialism of Robert M. Hutchins, focuses on the concept, orientation and praxis of learning, between progress or regression.

Keywords: Independent Campus, Thought Debate, Education 


\section{PENDAHULUAN}

\section{LATAR BELAKANG}

Kebijakan kampus merdeka, nyatanya diimplementasikan untuk mengatasi berbagai tantangan serta hambatan pada era modern yang semakin dinamis serta kompleks. Tentu kebijakan tersebut merupakan bukti orientasi pendidikan tinggi Indonesia yang mengarah pada upaya pemenuhan hak-hak mahasiswa, sebagai warga negara. Tentu realitas tersebut merupakan awal pendidikan tinggi Indonesia yang bersifat modern dan berkualitas, dengan tetap berbasis pada Pancasila dan UUD 1945, karena kualitas pendidikan tinggi, memiliki dampak kepada keefektifan dalam mengelola bonus demografi. Terlebih Indonesia akan mengalami karunia tersebut, sehingga konsep dan praksis pendidikannya perlu mendukung, agar bonus demografi bangsa Indonesia, tidak menimbulkan dampak seperti pengangguran yang mengarah pada kemiskinan.

Berdasarkan informasi Kemendikbud (2017) ditegaskan bahwa Indonesia diproyeksi akan menjadi kekuatan ekonomi terkuat ke-5 pada 2045, serta menyumbang 38\% dari jumlah penduduk produktif ASEAN, tentu merupakan peluang bagi Indonesia untuk menjadi negara berpengaruh di kawasan Asia Pasifik. Sehingga peran kebijakan pendidikan lebih berfokus pada upaya pengelolaan peserta didik dan mahasiswa agar mampu membawa bangsa menuju puncak peradabannya. Termasuk kebijakan kampus merdeka, yang menghendaki kemerdekaan dan modernisasi pendidikan, tentu perlu bermakna bahkan berdampak nyata pada perkembangan mahasiswa, agar menjadi warga negara muda yang memiliki kecerdasan, keterampilan serta sikap yang mumpuni. Nanggala dan Suryadi (2020, hlm. 11) memaparkan bahwa kampus merdeka menjadi solusi bersifat alternatif atas berbagai tantangan pada era modern, karena merupakan kebijakan aktual pada pendidikan tinggi, sebagai upaya untuk mengoptimalkan eksistensi perguruan tinggi, agar kesenjangan kualitas pendidikan serta pelayanannya bisa terselesaikan.

Sebelum mengarah pada penerapan, tentu kebijakan pendidikan, perlu memiliki landasan teori yang kuat. Sehingga memiliki substansi, orientasi serta strategi yang jelas, agar kebijakan tersebut bejalan secara efektif, guna meminimalisir terwujudnya kebijakan yang sebatas pada wacana bahkan prosedural saja, yang tidak memiliki dampak nyata bagi penguatan kapasitas sumber daya manusia yang berkarakter, berdaya saing juga unggul. Karena hasil dari kebijakan pendidikan, tentu tidak bisa dianalisis serta evaluasi sekaligus, tetapi bersifat kontinuitas, karena merupakan realisasi dari investasi sumber daya manusia, terlebih bagi Indonesia, karena pemerataan kualitas pendidikan, masih menjadi masalah yang bersifat klasik. Nanggala (2020, hlm. 54) menjelaskan bahwa hambatan majunya pendidikan Indonesia: 1) belum meratanya kualitas pendidikan, 2) kesenjangan fasilitas, sarana serta prasarana, 3) masih tersedianya fenomena KKN melalui oknum, 4) belum meratanya kualitas guru, hingga ke penjuru Indonesia, 5) realisasi anggaran pendidikan yang belum optimal.

Diinformasikan pada Buku Panduan Merdeka Belajar-Kampus Merdeka (2020) bahwa orientasi penting kebijakan kampus merdeka adalah untuk menginternalisasikan pengetahuan, mengasah keterampilan milik mahasiswa, menumbuhkan kepekaan sosial serta membentuk karakter mahasiswa. Tentu orientasi tersebut begitu merepresentasikan aliran filsafat pendidikan progresivisme, yang menghendaki terjadinya kemerdekaan serta modernisasi pada bidang bidang pendidikan, agar berdampak nyata terhadap mahasiswa. Tetapi orientasi tersebut juga secara minimal merepresentasikan aliran filsafat pendidikan perenialisme, karena berorientasi membentuk karakter atau kepribadian milik mahasiswa. Pada substasinya konsep kemerdekaan pada bidang pendidikan dalam pandangan tokoh pendidikan Indonesia, tentu mengarah pada Ki Hajar Dewantara, karena memberikan sumbangsih mengenai pendidikan yang ideal, sehingga perlu diberlakukan oleh bangsa Indonesia, yang dikomprehensifkan melalui pemikiran pendidikan Paulo Freire, karena turut menghendaki terjadinya kebebasan pada pendidikan, agar tidak bersifat menindas juga membelenggu peserta didik. 
Tentu pemikiran pendidikan Ki Hajar Dewantara serta Paulo Freire, mengarah pada upaya konkret memberikan pendidikan yang merdeka, tetapi perbedaannya, yaitu Ki Hajar Dewantara lebih pada praksis membimbing tetapi Paulo Freire lebih pada membebaskan peserta didik atas belenggu serta penindasan pendidikan (Sopyan, dkk, 2020, hlm. 85). Sehingga kebijakan kampus merdeka perlu untuk dianalisis melalui perspektif pemikiran tersebut, sehingga meminimalisir terjadinya ketimpangan cita-cita dengan realitas, karena penerapan kebijakan yang sebatas prosedural. Tentu upaya analisis konsep kampus merdeka melalui perspektif pemikiran pendidikan $\mathrm{Ki}$ Hajar Dewantara serta Paulo Freire mengarah pada perdebatan mengenai pemikiran filsafat pendidikan progresivisme serta perenialisme, agar bersifat komprehensif. Dengan orientasi memberikan pemaparan argumentatif, agar civitas akademika mampu mempunyai posisi akademik pada realitas perdebatan tersebut, yang mengarah pada pengembangan kajian teoretis pendidikan di Indonesia.

\section{METODE PENELITIAN}

Penelitian ini dilaksanakan melalui pendekatan kualitatif dengan metode studi literatur. Faktanya penelitian kualitatif yang tidak dibatasi melalui kategori tertentu, serta sifatnya yang mendalam bahkan elaboratif, tentu berdampak pada tertariknya peneliti untuk mengoptimalkan pendekatan tersebut pada penelitian yang berorientasi menelaah konsep kampus merdeka dalam perspektif pemikiran Ki Hajar Dewantara dan Paulo Freire serta untuk menganalisis perdebatan pemikiran aliran filsafat pendidikan John Dewey vs Robert M. Hutchins. Sumber pada penelitian ini difokuskan pada jurnal sebagai sumber rujukan primer, karena memiliki nilai keabsahan yang tinggi, dengan didukung oleh dokumen resmi negara sebagai sumber yang bersifat sekunder, sehingga meminimalisir terjadinya kesalahan penelitian yang bersifat prosedural, konseptual bahkan praktis. Tentu analisis data pada penelitian ini menggunakan teknik analisis data kualitatif dari Miles dan Huberman (dalam Wibowo dan Wahono, 2017, hlm. 197) yang mengarah pada: reduksi data, display data, verifikasi serta penarikan kesimpulan.

\section{HASIL DAN PEMBAHASAN}

\section{1) Kebijakan Kampus Merdeka Dalam Perspektif Pemikiran Ki Hajar Dewantara dan Faulo Freire}

Tentu analisis bersifat ringkas yang dilakukan oleh peneliti, berorientasi terhadap upaya memberikan informasi argumentatif, mengenai kampus merdeka dalam perspektif pemikiran Ki Hajar Dewantara bahkan Paulo Freire. Karena pemikiran kedua tokoh yang berfokus pada pendidikan tersebut, memiliki relevansi, yaitu turut menghendaki terjadinya kemerdekaan dan kebebasan pada konsep dan praksis pendidikan. Sehingga mengarah pada upaya mengoptimalkan minat, bakat bahkan orientasi dari peserta didik atau mahasiswa, agar memiliki keterampilan yang beragam bahkan mendalam, sehingga menjadi warga negara yang berkompeten juga mampu untuk diandalkan negara. Memberikan pendidikan dan pembelajaran yang mengakomodir suatu kebebasan atau kemerdekaan, tentu menjadi keniscayaan dalam membentuk peserta didik atau mahasiswa, sehingga mampu mengasah berbagai keahliannya. Terlebih kebijakan kampus merdeka mengakomodir terjadinya kemerdekaan, demokratisasi dan modernisasi pada konsep serta praksis pendidikan tinggi di Indonesia, tentu perlu dianalisis melalui perspektif pemikiran Ki Hajar Dewantara dan Paulo Freire, agar implementasi kebijakan kampus merdeka tidak bersifat pragmatis dan seremonial.

Ki Hajar Dewantara serta Paulo Freire merupakan seorang aktivis serta pengamat pendidikan, nyatanya mereka turut memberi kritik pada konsep serta praksis pendidikan juga pembelajaran yang menobatkan peserta didik atau mahasiswa hanya sebatas objek pembelajaran, sehingga berdampak terhadap tidak efektifnya transformasi kreatifitas, daya kritis, inovasi serta aktivitas pengembangan individu. Tentu diberlakukannya kebijakan kampus merdeka, mengarah terhadap upaya konkret untuk mengatasi fakta pembelajaran tersebut, dengan rasionalisasi, secara praksis pembelajarannya, lebih memfokuskan minat, 
bakat serta orientasi dari mahasiswa. Karena konsep serta praksis pembelajaran kampus merdeka berpusat pada mahasiswa, sehingga eksistensi dosen pada pembelajaran kampus merdeka lebih berfokus pada tanggung jawab sebagai mediator, pembimbing dan fasilitator untuk mahasiswa, supaya bisa berkembang secara komprehensif. Konsep pembelajaran tersebut, tentu merupakan perspektif tentang pendidikan bahkan pembelajaran yang ideal menurut Ki Hajar Dewantara serta Paulo Freire, yang selaras mengendaki terwujudnya kemerdekaan, demokratisasi atau kebebasan pada substansi pendidikan dan pembelajaran, sehingga peserta didik atau mahasiswa, tidak diklaim selaku objek pembelajaran saja, yang menimbulkan praksis pembelajaran bersifat prosedural, sehingga perubahan peserta didik atau mahasiswa ke arah positif, berjalan tidak optimal.

Perspektif Ki Hajar Dewantara, tentu percaya bahwa peserta didik atau mahasiswa memiliki potensi serta akal pikiran, atas fitrah selaku makhluk Tuhan Yang Maha Kuasa, sehingga konsep bahkan praksis pendidikan harus mengakomodir sistem among, karena memberikan bimbingan serta pelayanan, agar potensi serta akal pikiran peserta didik atau mahasiswa bisa diberdayakan secara optimal. Realisasi pembelajaran perlu mengakomodir kemerdekaan untuk peserta didik, khususnya pada pikirannya, raganya, maupun tenaganya, sehingga mengarah pada pendidikan berdasar humanisme, karena selalu mengedepankan keterbukaan bahkan dilandasi oleh sifat kasih sayang (Dewantara, dalam Istiq'faroh, 2020, hlm. 1). Tentu Ki Hajar Dewantara memiliki pandangan bahwa pendidikan adalah upaya bersifat mulia, sehingga orientasinya tidak terbatas pada transformasi ranah pengetahuan saja bagi peserta didik atau mahasiswa, tetapi bersifat komprehensif, sehingga merupakan wahana transformasi nilai, etika, keadaban, sifat, peserta didik atau mahasiswa, bahkan mengembangkan potensi, sebagai investasi sosial melalui kemerdekaan pendidikan serta pelayanan bersifat penuh. Dewantara (dalam Noventari, hlm. 86) menjelaskan pendidikan yang merdeka secara lahir bahkan batin harus diterima oleh peserta didik, dengan didukung melalui sistem among (membimbing), untuk mengembangkan potensi peserta didik secara optimal, karena sistem among mengakomodir pembelajaran partisipatif dan menyenangkan, sehingga dimandatkan sebagai tamansiswa.

Faktanya perspektif pemikiran Faulo Freire menegaskan pendidikan tidak boleh menindas peserta didik, karena tidak bersifat humanis, juga cenderung untuk menghambat kreatifitas serta daya kritis mereka, sehingga praktik pendidikan perlu didasari oleh metode hadap masalah, karena peserta didik diberi ruang bereksplorasi serta berpikir kritis untuk mengatasi problematik pribadi dan sosialnya. Fadli (2020, hlm. 100) memaparkan metode hadap masalah Paulo Freire mengakomodir peserta didik sebagai subjek pembelajaran, sehingga metode tersebut menjadi wahana peserta didik untuk belajar menyelesaikan masalah pribadi serta sosial secara kritis juga kreatif, guna mengembangkan minat bahkan bakat milik peserta didik. Nyatanya metode hadap masalah menjadi praktik atas konsep pendidikan liberal, sebagai solusi alternatif dari Paulo Freire, dalam mengatasi realitas pendidikan yang bersifat menindas bahkan membelenggu peserta didik, pendidikan yang liberal, nyatanya mengakomodir peserta didik untuk menjadi warga negara yang memiliki beragam kompetensi untuk karier juga untuk mengatasi problematik sosial. Freire (dalam Prahani, dkk, 2020, hlm. 31) mengungkapkan pentingnya kebebasan pendidikan, sehingga peserta didik tidak diklaim sebagai wadah bersifat kosong, diisi sampai penuh, seperti metode menabung di bank, faktanya metode tersebut tidak manusiawi, karena cenderung menindas serta mengakibatkan kreatifitas dan daya kritis peserta didik tidak diberdayakan.

Tentu kemerdekaan pada pendidikan yang diesensikan oleh Ki Hajar Dewantara, mengarah pada pembelajaran yang mampu mengoptimalkan potensi milik peserta didik, karena eksistensinya sebagai makhluk Tuhan Yang Maha Kuasa, tentu didukung melalui bimbingan serta pelayanan secara optimal bahkan menyenangkan kepada mereka. Panca Dharma menjadi esensi indikator pendidikan yang merdeka, sebagai berikut: 1) kodrat alam, sebagai makhluk ciptaan Tuhan YME, 2) 
kemerdekaan, pendidikan yang berbasis kemerdekaan, 3) kebudayaan, pendidikan untuk membangun budaya, 4) kebangsaan, pendidikan transformasi nasionalisme serta patriotisme, 5) humanis, pendidikan untuk memanusiakan manusia (Dewantara dalam Marwah, dkk, 2018, hlm. 18-19). Tentu pada konteks pendidikan liberal atau kebebasan dalam pendidikan yang dicetus oleh Paulo Freire, nyatanya mengarah terhadap upaya membebaskan peserta didik atas berbagai macam belenggu bahkan penindasan dalam konsep juga praksis pendidikan, karena tidak relevan pada hakikat pendidikan. Pendidikan liberal menjadi solusi mengatasi penindasan pendidikan, karena berbasis, 1) humanisasi, memenuhi fitrah manusia, 2) metode hadap masalah, mengakomodir peserta didik dalam mengatasi masalah sosial, 3) dialog, praktik atas kebebasan pendidikan, 4) kosientisasi, kesadaran peserta didik untuk berpartisipasi mengoptimalkan pendidikan (Freire dalam Rohinah, 2019, hlm. 6-7).

Tentu melalui informasi argumentatif tersebut, mampu ditegaskan bahwa kebijakan kampus merdeka, sangat merepresentasikan perspektif pemikiran pendidikan milik Ki Hajar Dewantara serta Paulo Freire, karena mengarah pada praksis pembelajaran yang berfokus kepada mahasiswa, terlebih realitas praktis pembelajaran kampus merdeka yang bersifat modern, demokratis, kontekstual dan memberi kesempatan bagi mahasiswa untuk berkembang selaras minat serta bakatnya. Siregar, dkk (2020, hlm. 143) memaparkan kebijakan kampus merdeka menjadi wahana mahasiswa dalam memperoleh kompetensi pengetahuan, sikap serta keterampilan yang komprehensif, dengan rasionalisasi praksis pembelajarnnya bersifat eksploratif, beragam bahkan selaras terhadap kebutuhan pada era modern. Nyatanya melalui Buku Panduan Merdeka Belajar-Kampus Merdeka (2020) ditegaskan bahwa praksis pembelajaran pada kebijakan kampus merdeka mengarah pada pertukaran pelajar, magang atau praktik kerja, asistensi mengajar pada satuan pendidikan, riset, kegiatan kemanusiaan, kewirausahaan, proyek independen bahkan membangun desa atau KKN bersifat tematik. Tentu praksis pembelajaran tersebut begitu mencerminkan konsep juga praksis atas pembelajaran ideal menurut perspektif Ki Hajar Dewantara serta Paulo Freire, yang berargumentasi bahwa peserta didik bahkan mahasiswa merupakan subjek atas pembelajaran, sehingga mereka perlu diberikan hak-haknya, karena menjadi bagian integral dari warga negara.

\section{2) Perdebatan Pemikiran John Dewey Vs Robert M. Hutchins}

Tentu perdebatan mengenai kemajuan dengan pendidikan konservatif, selalu terjadi dalam dunia pendidikan dan sosial, baik pada tataran perdebatan ilmiah, upaya perumusan kebijakan, juga praksis pembelajaran. Karena persepktif pemikiran tersebut, pada basisnya memiliki perbedaan bersifat mencolok, akibat perbedaan orientasi, kemajuan diwakili oleh aliran filsafat pendidikan progresivisme, dan konservatif tercermin melalui aliran filsafat pendidikan perenialisme. Progresivisme tentu menghendaki modernisasi bahkan kebebasan pada pendidikan, tetapi perenialisme begitu menghendaki pendidikan yang memberikan pengetahuan bersifat kebenaran abadi, untuk peserta didik. Perspektif pemikiran tersebut, telah mengakibatkan terwujudnya berbagai gerakan pendidikan secara masif, khususnya di Amerika dan Eropa Barat, sehingga upaya dalam menjelaskan perdebatan teori tersebut menjadi upaya dalam memantapkan posisi keilmuan civitas akademika terhadap realitas perdebatan teori tersebut, sehingga praksis perdebatannya melalui pemikiran tokoh yang mencetus filsafat pendidikan progresivisme serta filsafat pendidikan perenialisme, yaitu John Dewey serta Martin M. Hutchins.

Konsep dan praksis pendidikan yang beradaptasi pada modernisasi dan mengarah terhadap orientasi pembelajaran berdampak nyata dan bermakna untuk peserta didik atau mahasiswa, adalah karakteristik utama aliran filsafat pendidikan progresivisme. Nyatanya realitas modernisasi berpengaruh terhadap terbuka dan sengitnya kompetisi, sehingga peserta didik atau mahasiswa perlu dibakali pengetahuan yang berkualitas, karakter yang positif, bahkan keterampilan yang beragam juga mendalam, supaya bisa bertahan hidup, karena memiliki modal akademik dan sosial, 
bahkan eksistensinya mampu berguna bagi lingkungan hidup dan dunia sosialnya. John Dewey merupakan seorang penggagas aliran filsafat pendidikan progresivisme, faktanya filsafat pendidikan tersebut bisa memperoleh respons positif dari civitas akademika dan masyarakat, karena berfokus pada tujuan bahkan praksis pendidikan yang berdampak nyata (pragmatis), khususnya bagi individu juga kelompok. Dewey (dalam Palvis dan Gkiosos, 2017, hlm. 27) memaparkan bahwa kebutuhan serta tantangan pada modernisasi bersifat kompleks dan dinamis, lalu manusia memiliki orientasi bahkan inovasi, sehingga pendidikan harus bisa beradaptasi terhadap realitas modernisasi bahkan mengakomodir kebebasan atau kemerdekaan, pada praksis kebijakan juga implementasi pembelajaran.

Progresivisme sebagai aliran fisafat pendidikan, merupakan respons dari praksis pendidikan Amerika pada abad ke-20 yang bercorak otoriter dan tradisional, yang hanya memfokuskan peserta didik sebagai objek pembelajaran saja, kampanye progresivisme pendidikan, tentu dipengaruhi pembaharuan pendidikan di Eropa Barat (Fadlillah, 2017, hlm. 19). Nyatanya pada tataran kebijakan pendidikan, perspektif progresivisme begitu menekankan konsep serta praksis kebijakan pendidikan yang mengoptimalkan eksistensi teknologi, mengakomodir kebebasan peserta didik atau mahasiswa yang mengarah pada upaya memperkuat minat serta bakatnya, bahkan dihabituasikan mengenai kepribadian serta kepekaan sosial yang positif terhadap peserta didik atau mahasiswa. Pada konteks pembelajarannya, aliran filsafat pendidikan progresivisme, tentu mengarah pada praksis pembelajaran bersifat aktif, menyenangkan, elaboratif, mengasah inovasi, kreatifitas juga daya kritis peserta didik atau mahasiswa, sehingga berbasis student centered learning, tentu pendidik pada praksis melaksanakan pembelajaran perlu memberdayakan realitas kemajuan teknologi, mengoptimalkan model pembelajaran modern, bahkan mewujudkan pembelajaran yang eksploratif. Pembelajaran dalam progresivisme bertujuan membentuk peserta didik atau mahasiswa, agar menjadi pribadi yang dewasa, melalui pembelajaran yang utuh dan modern, tentu progresivisme berorientasi membina peserta didik menjadi warga negara demokratis, bahkan memiliki keterampilan sebagai modal baginya dalam menggapai masa depan (Pecore dan Bruce, 2013, hlm. 10).

Faktanya Aliran filsafat pendidikan progresivisme merupakan sebuah gerakan pembaharuan pendidikan, yang masif serta berfokus pada modernisasi juga kebebasan pendidikan, setelah disosialisasikan secara utuh oleh John Dewey. Tentu aliran tersebut berorientasi pada terwujudnya pendidikan bahkan pembelajaran yang bersifat adaptif pada realitas modernisasi, sehingga praksis pembelajarannya berfokus pada peserta didik atau mahasiswa, agar terwujudnya konsep eksploratif demokratis, dan partisipatif, yang ditopang melalui optimalisasi teknologi, guna mengefektifkan praksis pembelajaran. Tentu substansi pembelajaran yang berdasar filsafat pendidikan progresivisme bertujuan untuk mengupayakan pembelajaran dampak nyata serta bermanfaat pada perkembangan peserta didik atau mahasiswa, sebagai modal untuk berkarier bahkan mengatasi masalah sosial, karena tujuan pembelajarannya yang bersifat komprehensif, dengan rasionalisasi berfokus pada pengetahuan, sikap dan mengakomodir minat, bakat serta orientasi peserta didik atau mahasiswa, agar mereka memiliki keahlian yang mendalam bahkan beragam. Perspektif progresivisme memiliki pandangan bahwa dunia selalu berubah, sehingga pendidikan tidak boleh statis, karena berdampak pada ketimpangan antara kebutuhan dan tantangan zaman dengan materi dan tujuan pendidikan, mengakibatkan pendidikan harus progresif, agar, pendidikan dan pembelajaran, memiliki nilai kebermanfaatan bagi peserta didik atau mahasiswa, sehingga mereka mampu tumbuh sesuai dengan orientasinya.

Tentu pandangan pendidikan tersebut mendapatkan kritik dari Robert M. Hutchins, karena pendidikan yang selalu beradaptasi terhadap realitas modernisasi, tidak memiliki konsistensi, identitas juga bersifat oportunis, sehingga cenderung meniadakan substansi pendidikan. Robert M. Hutchins memiliki perspekif bahwa pendidikan, wajib menjadi 
wahana untuk peserta didik atau mahasiswa dalam menemukan, menelaah, mendapatkan pengetahuan bersifat kebenaran yang hakiki, karena tabiat tersebut, pada waktu juga pada situasi yang bagaimana pun, tetap memiliki konsistensi, karena bersifat hakiki, sehingga pendidikan memiliki manfaat yang bersifat jangka panjang. Faktanya filsafat pendidikan perenialisme bertabiat regres atau mundur, karena berkeyakinan bahwa tradisi, nilai dan kebudayaan abad pertengahan atau zaman dahulu, adalah basis pendidikan yang begitu kokoh bahkan telah terbukti konsistensinya, sehingga pendidikan perlu mengarah pada realitas di atas, karena bisa menjadi modal sosial dan akademik untuk peserta didik atau mahasiswa, dalam bertahan hidup bahkan dalam membangun kehidupan sosial. Karena perspektif perenialisme memandang bahwa era modern, penuh dengan ketidakpastian, ketidakteraturan bahkan ketidakjelasan, fakta tersebut, perlu diperbaiki oleh pendidikan, sehingga pendidikan yang tidak beradaptasi terhadap modernisasi dan perubahan, tetapi pendidikanlah sebagai sumber perubahan.

Faktanya aliran filsafat pendidikan perenialisme berorientasi pada pembelajaran yang memberikan kebenaran bersifat hakiki kepada peserta didik atau mahasiswa, agar mereka tidak kehilangan identitas serta arah hidup kelak nanti. Sehingga aliran filsafat pendidikan tersebut, merupakan respons dari aliran filsafat pendidikan progresivisme yang berorientasi pada modernisasi atau kemajuan, yang berdampak pada biasnya identitas serta makna dari pendidikannya. Perspektif aliran Filsafat pendidikan perenalisme merupakan solusi terhadap progresivisme, perenialisme bersifat tradisional atau konservatif, karena meyakini prinsip umum serta nilai-nilai pada zaman dahulu atau pada abad pertengahan, adalah basis pendidikan yang berkompeten serta bersifat kuat (Habsari, 2013, hlm. 149). Perspektif perenialisme menegaskan bahwa filsafat progresivisme tidak memiliki dasar pendidikan yang kokoh, sehingga substansi pembelajarannya tidak jelas, karena bersifat adaptif pada kemajuan, yang berbeda dengan filsafat perenialisme karena bersifat regres, dengan tujuan melestarikan nilai, tradisi serta kebudayaan yang telah eksis sejak zaman dulu, guna menjadi dasar pendidikan, karena telah terbukti kapasitasnya.

Walau memiliki corak tradisional atau konservatif tetapi aliran filsafat pendidikan perenialisme, berkembang setelah perspektif filsafat pendidikan progresivisme menjadi kampanye pendidikan pada abad ke-20 di Amerika Serikat bahkan Eropa. Perenialisme secara murni, begitu dipengaruhi pemikiran Plato, tetapi atas kapasitasnya sebagai aliran filsafat pendidikan, tentu aliran perenialisme begitu merepresentasikan pemikiran Robert Maynard Hutchins, yang membuat beliau dimandatkan sebagai penggagas, atau tokoh mengenai filsafat pendidikan perenialisme. Hutchins (dalam siregar, 2016, hlm. 177) memaparkan bahwa pendidikan menerapkan pengajaran, pengajaran menginternalisasikan pengetahuan, pengetahuan adalah kebenaran, kebenaran di mana pun serta kapan pun selalu konsisten, sehingga pendidikan perlu menjadi wahana peserta didik dalam mendapatkan dan menerapkan kebenaran yang bersifat kekal. Tujuan pembelajaran perenialisme mengarah pada upaya terbangunnya peserta didik atau mahasiswa, agar memiliki pengetahuan yang bersifat kebenaran hakiki, bahkan memiliki karakter, watak dan moralitas yang mumpuni, tujuan tersebut tentu mengarah pada beratnya tanggung jawab seorang pendidik, karena pada perspektif perenialisme, tentu pendidik berfokus untuk memberikan keteladanan.

Melalui informasi argumentatif di atas nyatanya bisa disimpulkan, bahwa John Dewey sebagai pencetus aliran progresivisme meghendaki modernisasi, keleluasaan serta demokratisasi pendidikan. Sehingga orientasi pendidikan mengarah terhadap peserta didik atau mahasiswa, baik dalam mengakomodir minat serta bakat mereka, maupun praksis pembelajarannya, yang merepresentasikan substansi student centered learning, bahkan memanfaatkan eksistensi teknologi, sehingga mendukung praksis pembelajarannya. Dalam konteks perspektif pemikiran Robert $M$. Hutchins tentang aliran filsafat pendidikan perenialisme, nyatanya menjadi respons serta solusi dari pandangan progresivisme, karena pendidikan yang beradaptasi terhadap realitas 
modernisasi tidak memiliki identitas bahkan oportunis, sehingga manfaatnya hanya sesaat. Pemikiran perenialisme memandang bahwa tujuan pendidikan serta pembelajaran perlu bersifat jangka panjang, melalui strategi dan upaya mentransformasikan kebenaran paling hakiki terhadap peserta didik atau mahasiswa, yang dioptimalkan melalui habituasi nilai, tradisi dan kebudayaan yang hidup sejak lama dalam masyarakat dan dunia sosial.

Ireiqat (2016, hlm. 2318) menjelaskan perspektif progresivisme serta perenialisme memiliki perbedaan yang mendasar, karena filsafat progresivisme bersifat progresif atau mengakomodir kemajuan, tetapi perenialisme bersifat regres, agar peserta didik mengetahui kebenaran abadi dan mengaplikasikan nilai serta kebudayaan yang telah hidup sejak dulu, sehingga bersifat tradisional. Nyatanya tidak ada aliran filsafat pendidikan yang bersifat paling sempurna dan benar, semua memiliki nilai kelebihan serta kekurangan, tetapi akan efisien apabila kebijakan pendidikan suatu negara, memiliki tujuan, substansi serta basis pendidikan yang tegas, sehingga mengetahui model aliran filsafat pendidikan yang paling kapabel untuk direalisasikan terhadap negara tersebut. Dalam menelaah bahkan memilih filsafat pendidikan sebagai landasan untuk menyusun suatu kurikulum pendidikan, agar menjadi rujukan pembelajaran, tentu perlu relevan pada ideologi nasional, modernisasi iptek, tantangan zaman, nilai, orientasi serta kebudayaan bangsa, membuat penyusunan kurikulum, lazimnya tidak berbasis filsafat pendidikan tunggal (Fernandes, 2019, hlm. 73). Perspektif John Dewey serta Robert M. Hutchins merupakan wahana analisis serta refleksi mengenai bagaimana orientasi serta struktur kurikulum yang kapabel dan ideal, agar dapat menghadapi berbagai masalah dan tantangan pendidikan, tetapi tidak merusak makna pendidikan serta pembelajaran yang didasari oleh ideologi bangsa, bahkan tujuan pendidikan nasional, karena pendidikan perlu memiliki mengakomodir modernisasi bahkan melestarikan kebudayaan bangsa.

\section{KESIMPULAN}

Kampus merdeka merepresentasikan perspektif pemikiran Ki Hajar Dewantara dan Paulo Freire, karena menghendaki terjadinya kemerdekaan serta keleluasaan pada konsep bahkan praksis pendidikan. Karena Ki Hajar Dewantara berpandangan bahwa pendidikan yang ideal adalah pendidikan yang merdeka bagi peserta didik, sehingga mereka mampu mengembangkan minat, bakat dan potensinya sebagai rahmat dari Tuhan Yang Maha Esa. Dalam konteks pemikiran pendidikan Paulo Freire, tentu kampus merdeka memberikan ruang lebih bagi mahasiswa agar berkembang dan bereksplorasi, dengan didukung melalui bentuk pembelajarannya yang beragam, guna memberikan kemerdekaan serta modernisasi. Sehingga begitu mencerminkan pendidikan Paulo freire, yang menegaskan pentingnya, kebebasan pada pendidikan, agar mahasiswa terbebas dari pembelajaran prosedural, serta terbebas dari peran yang hanya sebatas objek pembelajaran saja, terlebih kebijakan kampus merdeka mengakomodir konsep pendidikan berbasis sistem among dan pendidikan hadap masalah.

Perdebatan pemikiran yang mengarah pada kelebihan dan kekurangan aliran filsafat pendidikan progresivisme dan perenialisme, tentu telah berlangsung sejak lama. Karena kedua aliran filsafat tersebut, memiliki ciri, konsep bahkan orientasi yang berbeda secara mendasar, dengan rasionalisasi berfokus pada perdebatan mengenai sifat pendidikan yang beradaptasi pada modernisasi dan pendidikan yang menjadi sumber perubahan. Perspektif progresivisme disosialisasikan secara masif oleh John Dewey, filsafat pendidikan tersebut menghendaki modernisasi, kebebasan serta pembelajaran yang berfokus terhadap peserta didik, sehingga pendidik berfokus sebagai pembimbing, mediator dan fasilitator. Pada konteks perspektif perenialisme merupakan kebalikan dari progresivisme, tentu bersifat konservatif atau tradisional, aliran tersebut disosialisasikan Robert M. Hutchins, sebagai respons atas progresivisme yang membuat pendidikan menjadi pragmatis, karena aliran perenialisme berorientasi pada upaya untuk memberikan pengetahuan bersifat kekal pada 
peserta didik, sehingga pendidikan memiliki tugas berat, yaitu memberi keteladanan.

\section{DAFTAR PUSTAKA}

Direktorat Jenderal Pendidikan Tinggi. (2020). Buku Panduan Merdeka BelajarKampus Merdeka. Jakarta: Kemendikbud.

Fadli, R. V. (2020). Tinjauan Filsafat Humanisme: Studi Pemikiran Paulo Freire dalam Pendidikan. Reforma: Jurnal Pendidikan dan Pembelajaran, 9(2), 96-103. doi: https://doi.org/10.30736/rf.v9i2.317

Fadlillah, M. (2017). Aliran Progresivisme dalam Pendidikan di Indonesia. Jurnal Dimensi Pendidikan dan Pembelajaran, 5(1), 17-24. doi: http://dx.doi.org/10.24269/dpp.v5i1. $\underline{322}$

Fernandes, R. (2019). Relevansi Kurikulum 2013 dengan kebutuhan Peserta didik di Era Revolusi 4.0. Jurnal Socius: Journal of Sociology Research and Education, 6(2), 70-80. doi: https://doi.org/10.24036/scs.v6i2.157

Kementerian Pendidikan dan Kebudayaan. (2017). Peta Jalan Generasi Emas Indonesia 2045. Jakarta: Kemendikbud.

Habsari, N. T. (2013). Implementasi Filsafat Perenialisme dalam Pembelajaran Sejarah. Jurnal Sejarah dan Pembelajarannya, 3(1), 149-159. doi: http://doi.org/10.25273/ajsp.v3i01.90 $\underline{8}$

Ireiqat, N. (2016). Philosophies of Education. The International Journal of Social Sciences and Humanities Invention, 3(6), 2318-2322. doi: 10.18535/ijsshi/v3i6.12

Istiq'faroh, N. (2020). Relevansi Filosofi Ki Hajar Dewantara sebagai Dasar Kebijakan Pendidikan Nasional Merdeka Belajar di Indonesia. Lintang Songo: Jurnal Pendidikan. 3(2), 1-10.

Marwah, S. S., Syafe'i, M. \& Sumarna, E. (2018). Relevansi Konsep Pendidikan menurut Ki Hadjar Dewantara dengan
Pendidikan Islam. Tarbawy: Indonesian Journal of Islamic Education, 5(1), 14-26. doi: https://doi.org/10.17509/t.v5i1.13336

Nanggala, A. (2020). Analisis Wacana Pembaharuan Kebijakan Zonasi Menteri Pendidikan dan Kebudayaan Nadiem Makarim sebagai Solusi Pemerataan Pendidikan di Indonesia. Jurnal Pendidikan Kewarganegaraan Undiksha, 8(2), 46-56. doi: http://dx.doi.org/10.23887/jpku.v8i2. 24758

Nanggala, A. \& Suryadi, K. (2020). Analisis Konsep Kampus Merdeka dalam Perspektif Pendidikan Kewarganegaraan. Jurnal Global Citizen, 9(2), 10-23. doi: http://dx.doi.org/10.33061/jgz.v9i2.4 $\underline{545}$

Noventari, W. (2020). Konsepsi Merdeka Belajar Dalam Sistem Among Menurut Pandangan Ki Hajar Dewantara. PKn Progresif: Jurnal Pemikiran dan Penelitian Kewarganegaraan, 15(1), 83-91. doi: https://doi.org/10.20961/pknp.v15i1. $\underline{44902}$

Palvis, D. \& Gkiosos, J. (2017). John Dewey, From Philosophy of Pragmatism to Progressive Education. Journal of Arts \& Humanities, 6(9), 23-30. doi: https://doi.org/10.18533/journal.v6i9 .1257

Pecore, J. L. \& Bruce, B. C. (2013). Editorial for Progressive Education: Antecedents of Educating for Democracy. International Journal of Progressive Education, 9(1), 10-13.

Prahani, B. K. Deta, U. A. Yasir, M. Astutik, S. Pandiangan, P. Mahtari, S. Mubarok, H. (2020). The Concept of "Kampus Merdeka" in Accordance with Freire's Critical Pedagogy. Studies in Philosophy of Science and Education (SiPoSE), 1(1), 21-37. doi: https://doi.org/10.46627/sipose.v1i1. $\underline{8}$ 
Rohinah. (2019). Re-Konsientisasi dalam Dunia Pendidikan (Membangun Kesadaran Kritis melalui Pemikiran Paulo Freire). Jurnal Tarbiyah: Jurnal Ilmiah Kependidikan, 8(1), 1$12 . \quad$ doi: https://dx.doi.org/10.18592/tarbiyah. v8i1.2355

Siregar, N. Sahirah, R. \& Harahap, A. A. (2020). Konsep Kampus Merdeka Belajar di Era Revolusi Industri 4.0. Fitrah: Journal of Islamic Education (FJIE), 1(1), 142-157.

Siregar, R. L. (2016). Teori Belajar Perenialisme. Jurnal Al-hikmah, 13(2), 172-183. doi: https://doi.org/10.25299/alhikmah:jaip.2016.vol13(2).1522

Sopyan, A. Firmansyah, S. R. \& Koswara, D. (2020). Pemikiran Humanistik dalam Pendidikan (Perbandingan Pemikiran Paulo Freire dengan Ki Hajar Dewantara). Jurnal Al-Karim: Jurnal Pendidikan Psikologi dan Studi Islam, 5(1), 67-87.

Wibowo, A. P. \& Wahono, M. (2017). Pendidikan Kewarganegaraan: Usaha Konkret untuk Memperkuat Multikulturalisme di Indonesia. Jurnal Civics: Media Kajian Kewarganegaraan, 14(2), 198-202. doi:

https://doi.org/10.21831/civics.v14i2 $\underline{.16043}$ 